\section{Influence of Storage Strategies on the Reactivation Characteristics of Shortcut Nitrification Aerobic Granular Sludge}

\author{
L. Yan, ${ }^{\mathrm{a},{ }^{*}}$ Y. Guo, ${ }^{\mathrm{a}}$ X. Zhang, ${ }^{\mathrm{a}}$ L. Yu, ${ }^{\mathrm{a}}$ X. Bao, ${ }^{\mathrm{a}}$ \\ G. Hao, ${ }^{a}$ Z. Chen, ${ }^{b}$ and Y. Ren ${ }^{b, *}$ \\ ${ }^{a}$ School of Resource and Environment, Northeast \\ Agricultural University, Harbin 150030 China \\ ${ }^{b}$ School of Municipal and Environmental Engineering, \\ Harbin Institute of Technology, Harbin 150090, China
}

doi: 10.15255/CABEQ.2016.960

Original scientific paper

Received: July 29, 2016

Accepted: March 12, 2017

\begin{abstract}
Appropriate storage strategies were helpful in keeping the integrity and activity as well as in promoting the engineering application of granular sludge. The particle size distribution, composition of extracellular polymeric substances (EPSs), and activity of shortcut nitrification aerobic granular sludge (SNAGS) of the different storage strategies $\left(15^{\circ} \mathrm{C}\right.$ with intermittent aeration, $4{ }^{\circ} \mathrm{C},-20^{\circ} \mathrm{C}$, and $\left.-80{ }^{\circ} \mathrm{C}\right)$ were investigated in this study. The results showed that the storage strategies influenced particle size distribution, EPSs, protein (PN), polysaccharide (PS), PN/PS, and the oxidation ability of ammonium nitrogen of SNAGS. However, storage strategies had little effect on nitrite accumulation. The particle size, EPSs, PN, and PS of the SNAGS decreased after storage. The change of EPSs, PN, and PS of SNGS was smaller under the storage condition of $-20{ }^{\circ} \mathrm{C}$. The ammonium nitrogen oxidation and denitrification abilities of SNAGS were highest under the storage condition of $-80^{\circ} \mathrm{C}$ and $-20{ }^{\circ} \mathrm{C}$.
\end{abstract}

Key words:

granular sludge, reactivation, storage strategies, EPSs

\section{Introduction}

As a promising wastewater treatment technology, granular sludge has more advantages than traditional flocs, such as the ability of microbial holding, sedimentation, and resisting impact load. Longer training time and long-term storage of granular sludge make the disintegration occur easily and limit the application of granular sludge ${ }^{1}$. In promoting the application of granular sludge technology, the storage of granular sludge becomes very meaningful.

The character and biological activity of granular sludge changed in the process of granular sludge storage $^{2}$; higher storage temperature will lead to the rapid disintegration of granular sludge. Lower storage temperature will increase operating cost. Therefore, storage conditions need to be optimized. The integrity and biological activity research of the long-term storage of granular sludge are reported in many reports: aerobic granular sludge was often stored in liquid media ${ }^{2-6}$. Tay et al. ${ }^{2}$ found that metabolic activity decreased obviously when granular sludge was stored for 7 weeks. Zhu et al. ${ }^{3}$ stored

"Corresponding author: Tel.: +86 451 55190825. E-mail address: yan1198@163.com, renyuanhit@163.com granular sludge for 7 weeks at room temperature, and granular sludge activity recovered successfully. Zeng et al. ${ }^{4}$ found that after granular sludge had been stored for 8 weeks at $4{ }^{\circ} \mathrm{C}$, the upper one-third of the particles produced black nuclei. Wang et al. ${ }^{5}$ recovered the nitrification ability and the chemical oxygen demand (COD) removal efficiency in about 2 weeks after granular sludge had been stored at a low temperature for 7 months. Wan et al. ${ }^{6}$ investigated granular sludge stored at $4{ }^{\circ} \mathrm{C}$ in five liquid media for more than 1 year, and the sludge was recovered in $24 \mathrm{~h}$.

Granular sludge is also stored in other ways, such as freezing ${ }^{7-9}$. Metabolic activities of the microbial stopped, which helped extend the storage time under freezing conditions. Adav et al. ${ }^{7}$ reported that, for the first time, aerobic granular sludge of phenol degradation was stored at $-20{ }^{\circ} \mathrm{C}$, wherein the structure and integrity of the granular sludge were not lost. Frozen granular sludge could keep its integrity and be recovered successfully ${ }^{7-9}$. Freezing would reduce microbial activity 9 . Gao et al. ${ }^{8}$ reported the influence of storage temperature on granular sludge, wherein storage temperature had a greater influence on the morphology structure and the physical and chemical properties of aerobic granular sludge. Among these properties, the structure of the 
Table 1 -Characteristics of aerobic granular sludge, influent and effluent of wastewater

\begin{tabular}{|c|c|c|c|c|}
\hline Sludge properties & Numerical value & \multirow{2}{*}{ Parameters } & \multicolumn{2}{|c|}{ characteristics of effluent and influent } \\
\hline \multirow{6}{*}{$\begin{array}{c}\operatorname{MLSS}\left(\mathrm{g} \mathrm{L}^{-1}\right) \\
\operatorname{VSS}\left(\mathrm{g} \mathrm{L}^{-1}\right)\end{array}$} & $9.37 \pm 0.25$ & & Average influent & Average effluent \\
\hline & $7.41 \pm 0.34$ & $\mathrm{COD}\left(\mathrm{mg} \mathrm{L}^{-1}\right)$ & $212.65 \pm 34.75$ & $30.64 \pm 16.87$ \\
\hline & & Ammonium nitrogen $\left(\mathrm{mg} \mathrm{L}^{-1}\right)$ & $442.85 \pm 15.91$ & $6.40 \pm 8.76$ \\
\hline & & Nitrite $\left(\mathrm{mg} \mathrm{L}^{-1}\right)$ & $0.01 \pm 0.01$ & $286.37 \pm 36.48$ \\
\hline & & Nitrate $\left(\mathrm{mg} \mathrm{L}^{-1}\right)$ & $0.22 \pm 0.13$ & $78.39 \pm 12.81$ \\
\hline & & $\mathrm{pH}$ & $7.95 \pm 0.31$ & $8.45 \pm 0.32$ \\
\hline
\end{tabular}

granular sludge kept at $4{ }^{\circ} \mathrm{C}$ is more advantageous than that at other temperatures. The sedimentation of granular sludge at $-25{ }^{\circ} \mathrm{C}$ is the best, and the ratio of PN to PS (PN/PS) shows no obvious change. $\mathrm{Lv}$ et al. ${ }^{9}$ stored sludge for 40 days at $-20{ }^{\circ} \mathrm{C}$ and then thawed and reactivated it in one day. In addition to placing the sludge in an anaerobic/anoxic state for a long time during storage, the interaction of aerobic and anaerobic/anoxic conditions was feasible in maintaining the activity of the sludge when the substrate was added regularly ${ }^{10}$. The alternation of aerobic/anaerobic state can affect the decline rate of cell if nitrogen (which was hydrolytic released by nitrifying bacteria oxidation cells) helped prolong starvation time. A lowered rate of reduction led to a quick recovery in the recovery phase ${ }^{10}$. The attenuation rate of nitrifying bacteria under alternating anaerobic/aerobic conditions was less than the rate of aerobic or anaerobic conditions ${ }^{11}$.

The storage of heterotrophic granular sludge was investigated in many studies, but the storage of autotrophic granular sludge was not significantly studied $^{5}$. The present study investigates the influence of the different storage strategies on the characteristics of shortcut nitrification aerobic granular sludge (SNAGS), which can remove organic matter and ammonium nitrogen simultaneously. The influence of different storage strategies on particle size distribution and the extracellular substance of granular sludge were investigated, and the recovery of pollutants under the conditions of room temperature and shortcut nitrification characteristics were also studied. In choosing the optimal storage strategy, the foundation for the preservation and engineering applications of granular sludge are established.

\section{Materials and methods}

\section{Cultivation of aerobic granular sludge}

The aerobic granular sludge was a shortcut nitrification granular sludge cultured in the laboratory for more than two years ${ }^{12}$. The particle sizes of the granular sludge are more than $1.0 \mathrm{~mm}$. The sludge characteristics and removal efficiency of the artificial wastewater are shown in Table 1.

\section{Storage test}

SNAGS mixtures were taken from the SBR reactor at the aeration stage, left to settle for $10 \mathrm{~min}$, separated from the supernatant, and then preceded as follows. A: The previously mentioned granular sludge was put into a $500 \mathrm{~mL}$ beaker, with $350 \mathrm{~mL}$ sewage, stored for one week at room temperature $\left(15{ }^{\circ} \mathrm{C}\right)$, changed with $50 \%$ wastewater, and then aerated for $6 \mathrm{~h}$. B: The granular sludge was then placed into a $500 \mathrm{~mL}$ beaker with $350 \mathrm{~mL}$ sewage, and stored at $4{ }^{\circ} \mathrm{C}$. C: The sludge was washed with distilled water, rinsed thrice, moved to a $500 \mathrm{~mL}$ wide-mouthed bottle, and stored at $-20{ }^{\circ} \mathrm{C}$. D: The sludge was washed with distilled water, rinsed thrice, moved to a $500 \mathrm{~mL}$ wide-mouthed bottle, and stored at $-80{ }^{\circ} \mathrm{C}$. Storage strategies of SNAGS are shown in Table 2.

\section{Reactivation test}

The sludge samples were stored for 4 weeks, after which they were taken out and placed in a 500 $\mathrm{mL}$ beaker to be tested for reactivation (SBR: work volume was $500 \mathrm{~mL}$, exchange volume ratio was 50 $\%$, operating temperature was $18-20{ }^{\circ} \mathrm{C}$, DO: $6-8$ $\left.\mathrm{mg} \mathrm{L}^{-1}\right)$. SBR runs two cycles every day, with each cycle involving $2 \mathrm{~min}$ of inflow, $360 \mathrm{~min}$ of aeration, 5 min of sedimentation, 2 min of drainage. The constituents of experimental synthetic wastewater are as follows: ammonium nitrogen, 386.63-

Table 2 -Different storage strategies of aerobic granules

\begin{tabular}{c|c|c|c|c}
\hline Treatment & $\begin{array}{c}\text { Storage } \\
\text { strategies }\end{array}$ & $\begin{array}{c}\text { Storage } \\
\text { media }\end{array}$ & $\begin{array}{c}\text { Storage } \\
\text { time }\end{array}$ & $\begin{array}{c}\text { Oxygen } \\
\text { supply }\end{array}$ \\
\hline A & $\begin{array}{c}15^{\circ} \mathrm{C} \text { with } \\
\text { intermittent wastewater }\end{array}$ & 4 weeks & Yes \\
B & $4{ }^{\circ} \mathrm{C} \quad$ wastewater & 4 weeks & No \\
C & $-20{ }^{\circ} \mathrm{C}$ & & 4 weeks & \\
D & $-80{ }^{\circ} \mathrm{C}$ & 4 weeks & \\
\hline
\end{tabular}


$449.80 \mathrm{mg} \mathrm{L}^{-1}$ (first stage: 1-25 d), 300.90-327.98 $\mathrm{mg} \mathrm{L}^{-1}$ (second stage: $26-30 \mathrm{~d}$ ), nitrite nitrogen and nitrate, below $1.0 \mathrm{mg} \mathrm{L}^{-1}$, COD, 170.27-248.96 $\mathrm{mg} \mathrm{L} \mathrm{L}^{-1}$, and $\mathrm{pH}, 7.5-9.0$, and a certain amount of trace elements are added to satisfy the growth of the microorganism ${ }^{12}$.

\section{Analytical methods}

The analysis of COD, ammonium, nitrite, nitrate nitrogen, mixed liquid suspended solids (MLSS), volatile suspended solid (VSS), were performed in accordance with the standard methods ${ }^{13}$. The measurement of $\mathrm{pH}$ was carried out with a pHS-3C precision $\mathrm{pH}$ meter (Shanghai Weiye Co., Ltd., China). The measurement of DO was carried out using a dissolved oxygen meter (Shanghai Leici Co., Ltd., JPB-607, China). EPSs were extracted using heating method ${ }^{14}$. Polysaccharide (PS) concentration was determined using the Anthrone method $^{15}$ and protein (PN) measurement was performed using a modified Lowry method ${ }^{16}$. UV absorbance was measured with a TU-1810 spectrophotometer (Pu xi tong yong Co., Beijing, China).

\section{Results and discussions}

\section{Influence of storage strategies on the particle size distribution of SNAGS}

When the storage temperature was $15{ }^{\circ} \mathrm{C}$ and the oxygen supply was intermittent (Fig. 1a), the particle size of SNAGS was mostly large, and the granular sludge quality greater than $1.0 \mathrm{~mm}$ accounted for $99.96 \%$ of the total quality, whereas the granular sludge quality greater than $1.7 \mathrm{~mm}$ accounted for $89.21 \%$ of the total quality. When the storage temperature was $4{ }^{\circ} \mathrm{C}$ (Fig. 1b), the particle size of SNAGS was mostly large, and the granular sludge quality greater than $1.0 \mathrm{~mm}$ accounted for $98.46 \%$ of the total quality. By contrast, the granular sludge quality greater than $1.7 \mathrm{~mm}$ accounted for $81.41 \%$ of the total quality. When the storage temperature was $-20{ }^{\circ} \mathrm{C}$ (Fig. 1c), the particle size of SNAGS was mostly large, and the granular sludge quality greater than $1.0 \mathrm{~mm}$ accounted for $94.04 \%$ of the total quality, whereas the granular sludge quality greater than $1.7 \mathrm{~mm}$ accounted for $70.11 \%$ of the total quality. When the storage tem-
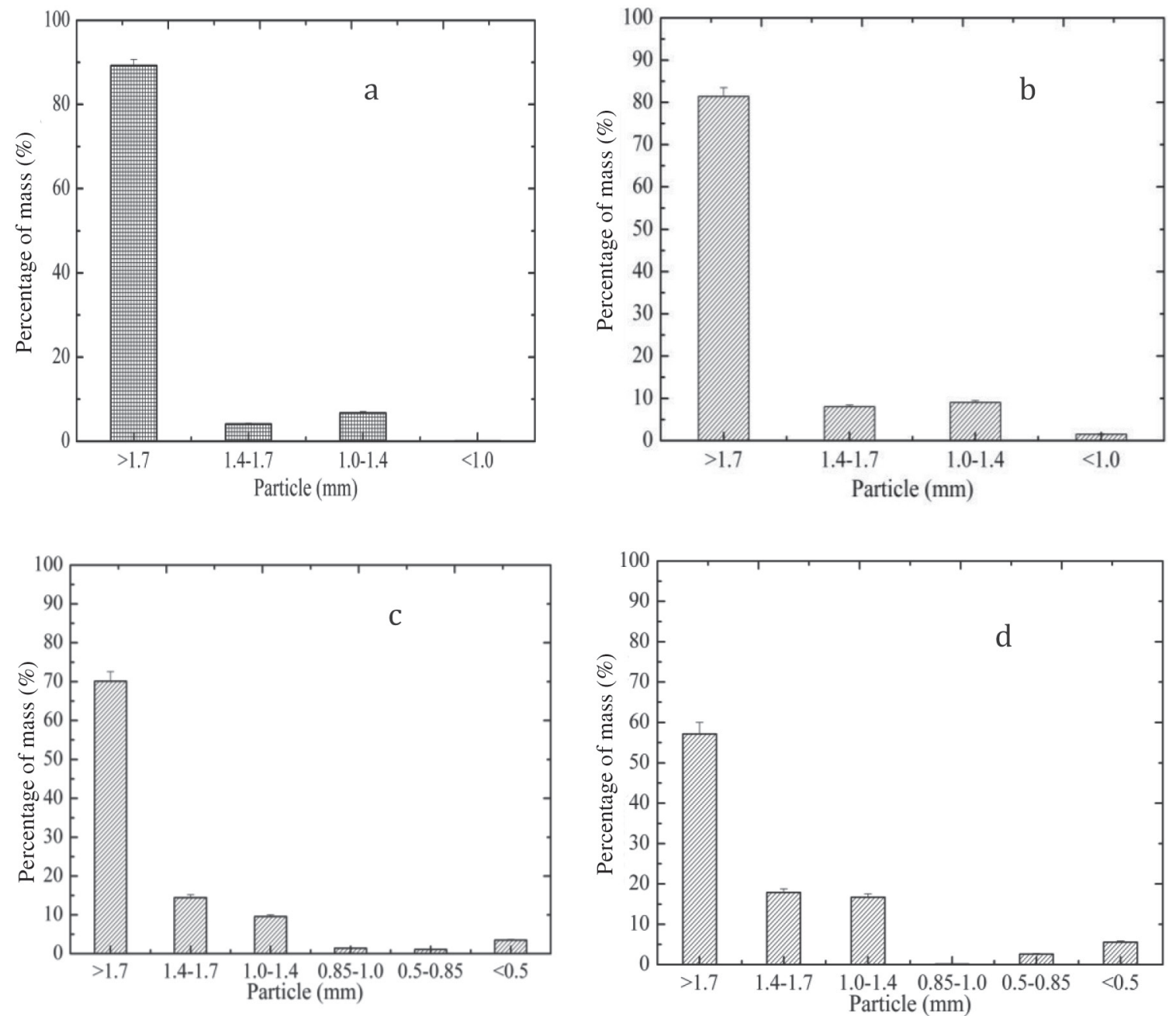

Fig. 1 - Particle size distribution of SNAGS after storage 
perature was $-80{ }^{\circ} \mathrm{C}$ (Fig. 1d), the particle size of granular sludge was mostly large, and the granular sludge quality greater than $1.0 \mathrm{~mm}$ accounted for $91.71 \%$ of the total quality, whereas the granular sludge quality greater than $1.7 \mathrm{~mm}$ accounted for $57.16 \%$ of the total quality.

After being stored at these four strategies, the SNAGS had still maintained its integrity. Although most of the sludge had large particle sizes, the particle size distribution of granular sludge would change with different storage strategies, and the weight of the granular sludge with particle size greater than $1.0 \mathrm{~mm}$ in diameter gradually reduced. A lower storage temperature implies a smaller proportion between the larger particles. The granular sludge was frozen at lower storage temperatures. The temperature inflicted certain damage to the morphology of granular sludge. In the aeration phase, granular sludge was broken and disassembled, which was consistent with the results of the advanced research ${ }^{8}$.

\section{Influence of storage strategies on the EPSs of SNAGS}

EPSs not only play an important role in the formation and stability of granular sludge, but also have a significant effect on the stability of stored granular sludge. After storage, EPSs were degraded and used up by the microorganisms ${ }^{17}$.

Fig. 2 shows that the storage strategies had a certain effect on the PN, PS, and EPSs of SNAGS. The contents of PN, PS, and EPSs was lower at 15 ${ }^{\circ} \mathrm{C}$ and $4{ }^{\circ} \mathrm{C}$, and contents of PN, PS, and EPSs achieved their maximum at $-20^{\circ} \mathrm{C}$. The microbial activity and hydrolysis rate of EPSs were higher under storage at higher temperatures, thus, the contents of PN and PS were lower when stored at higher temperatures ${ }^{2}$. However, the PN, PS, and PN/PS of the sludge at $15{ }^{\circ} \mathrm{C}$ were slightly higher than when stored at $4{ }^{\circ} \mathrm{C}$, perhaps because of the storage strategies and the regular aeration of the sludge at $15{ }^{\circ} \mathrm{C}$ (aerated for $6 \mathrm{~h}$ every week); regular aeration could reduce the use of EPSs, which helps maintain the complete structure of granular sludge. Under conditions of freezing then melting, the microbial activity in the granular sludge was restrained, so that the PN and PS contents of the granular sludge changed slightly.

The PS content of SNAGS had reduced by $60.20 \%, 67.50 \%, 60.20 \%$ and $41.34 \%$ under the conditions of the four storage strategies. The PS was used as an energy source material under hunger conditions $^{18,19}$. PN content showed similar trends with PN. In comparison, the reduced proportion of PN was less than PS, the PN reduced by $51.81 \%$, $62.42 \%, 5.25 \%$, and $51.81 \%$ under the conditions

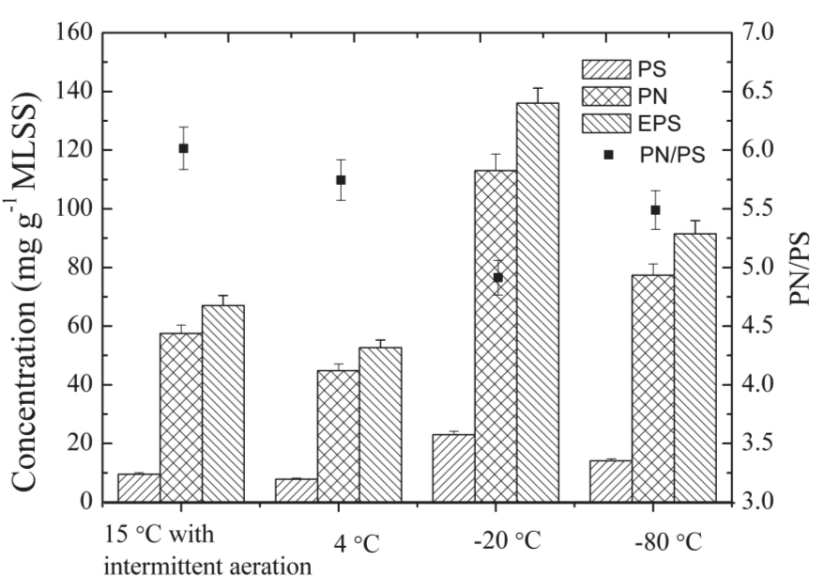

Fig 2 - EPSs, PN, and PS content and the ratio of protein/ polysaccharides (PN/PS) of the granules

of the four storage strategies. PN was reduced because the protein was hydrolyzed by protease ${ }^{20}$ in the process of storage.

The influence of the different storage strategies on the EPSs (in combination with PN and PS) of granular sludge was more pronounced. EPSs were reduced by $53.22 \%, 63.27 \%, 5.08 \%$, and $53.22 \%$ under the four storage strategies, which were mainly the reduction quantities of the PN. Granular sludge was mainly composed of $\mathrm{PN}$, and the increase in PN was helpful in keeping the stability of the granular sludge ${ }^{18}$.

Freezing and then melting resulted in a certain degree of destruction on the surface of the cell ${ }^{9}$ and led to the reduction in EPSs. The changes of PN, PS, and PN/PS of the granular sludge were smaller at $20^{\circ} \mathrm{C}$, which was consistent with Gaos' results ${ }^{8}$. In comparison, the storage temperature of $-80{ }^{\circ} \mathrm{C}$ may have caused more damage to the surface of the cell, which is characterized by the proportion of large-sized granular sludge reduced. Therefore, the EPSs declined.

\section{Reactivation performance of the granular sludge}

The SNAGS still showed high ammonium oxidation ability under the different storage strategies, the average ammonium oxidation abilities were 2.20, 2.50, 2.36, and $3.17 \mathrm{mg} \mathrm{g}^{-1} \mathrm{MLSS} \mathrm{h}^{-1}$ ) (Fig. $3 a)$. The ammonia oxidation ability of SNAGS in each reactor peaked in 3 days. Nitrifying bacteria can survive at very low concentrations of substrate, hunger, or volatile environments; they have low mortality rate and energy requirements ${ }^{20}$. The ability of ammonium oxidation is still present and can restore activity quickly after a period of storage ${ }^{21}$.

The ammonium nitrogen removal ability of SNAGS after storage was lower than before storage (3.89 $\mathrm{mg} \mathrm{g}^{-1} \mathrm{MLSS} \mathrm{h}^{-1}$ ). The presence of microorganisms in granular sludge resulted in endoge- 

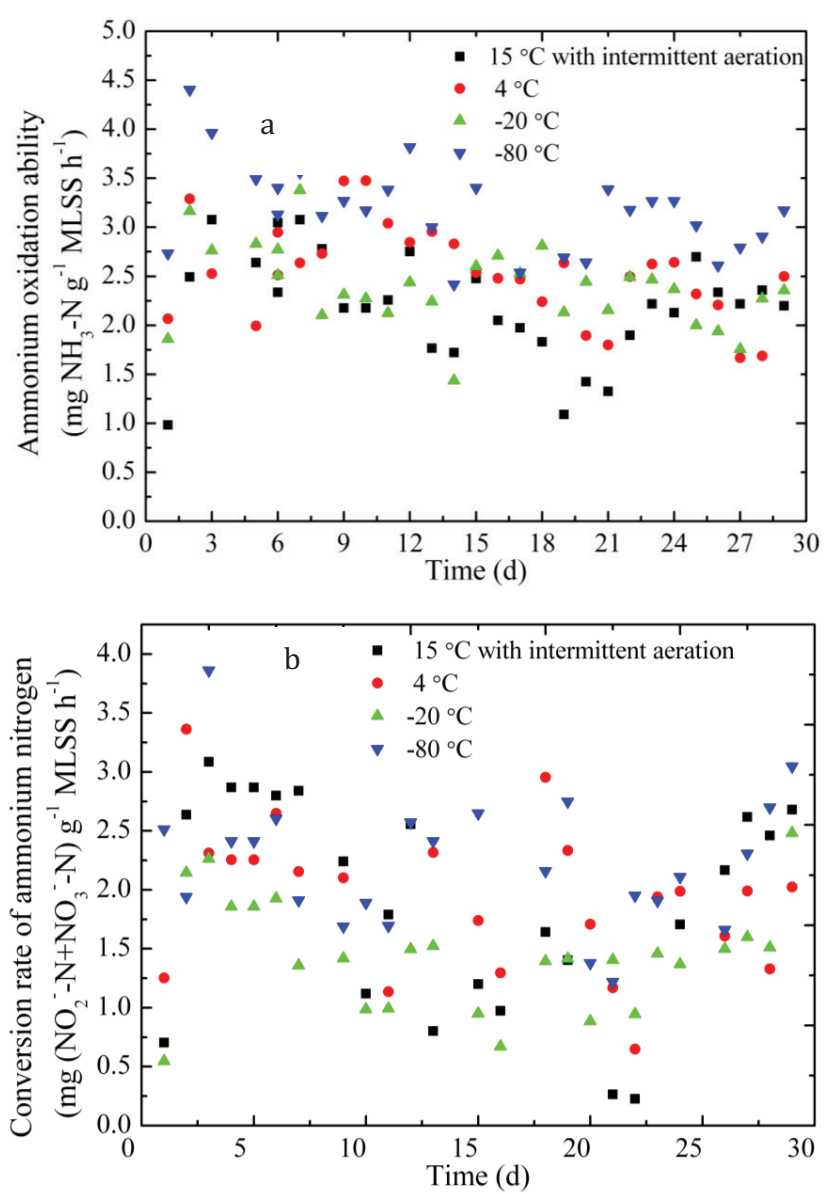

Fig. 3 - Ammonium oxidation ability and conversion rate of ammonium nitrogen during the reactivation period

nous respiration and intracellular hydrolysis, thereby leading to the loss of the biological activity of granular sludge ${ }^{2}$. At the same time, the inflow with high concentration of ammonium nitrogen restrained the activity of the nitrifying bacteria ${ }^{22}$. In addition, the $\mathrm{pH}$ value in the reactor was higher, deviated from the optimum $\mathrm{pH}$ range of the ammonium oxidizing bacteria, and limited the activity of ammonium oxidizing bacteria (Fig. 4). After being unused for 4 weeks, the effluent $\mathrm{pH}$ values in the four reactors were 8.93, 8.87, 9.49 and 9.43, which were higher than the optimal $\mathrm{pH}$ range of nitrifying bacteria, when the average inflow $\mathrm{pH}$ was around 8.07. The change in wastewater $\mathrm{pH}$ value in the reactors was related to the process of nitrification, air stripping, and the formation of organic substrates ${ }^{23}$. Generally, the biological nitrification process would consume the alkalinity in the wastewater and would cause a reduction in $\mathrm{pH}$ in the reaction system. However, in the test of the wastewater treatment process of high concentration of ammonium nitrogen, air stripping could remove ammonia and $\mathrm{CO}_{2}$ produced in the process of removing organic matter and caused by the increase in $\mathrm{pH}$ value in the reaction system. In addition, acetate as the source of organic substrates biological oxidation could also cause the increase in
$\mathrm{pH}$ value ${ }^{24}$. The comprehensive results mentioned above caused the effluent $\mathrm{pH}$ value to be higher than the inflow. However, after storage, the increase in $\mathrm{pH}$ value in the reaction system was higher than the inflow because of the limitation of biological nitrification.

The recoveries of the oxidation ability of ammonium nitrogen of SNAGS were affected by the storage strategies. The oxidation ability of ammonium nitrogen increased initially and then decreased gradually with time extension for storage strategy A (Fig. 3a). This result may be caused by the inhibiting effect of the high concentrations of FA in the inflow. When the ammonium nitrogen concentration was reduced to $300-330 \mathrm{mg} \mathrm{L}^{-1}$, the average oxidation ability of ammonium nitrogen was increased from 2.22 to $2.40 \mathrm{mg} \mathrm{g}^{-1} \mathrm{MLSS} \mathrm{h}^{-1}$. In storage strategies $\mathrm{B}, \mathrm{C}$, and $\mathrm{D}$, the oxidation abilities of ammonium nitrogen were different from that in strategy A. The ability did not increase after the concentration of ammonium nitrogen was adjusted in the inflow.

In clearing the effect of FA on the inflow of the treatment, the generation rate of nitrogen oxide $\left(\mathrm{NO}_{2}^{-}-\mathrm{N}+\mathrm{NO}_{3}^{-}-\mathrm{N}\right)$ was analyzed in the experiment (Fig. 3b). With the reduction in FA in the inflow, the generation rate of nitrogen oxide $\left(\mathrm{NO}_{2}^{-}-\mathrm{N}+\mathrm{NO}_{3}^{-}-\mathrm{N}\right)$ of the granular sludge for strategies $\mathrm{A}$ and $\mathrm{D}$ showed an overall increase. However, the variations of the generation rate were not obvious for strategies B and C. Therefore, the operating strategies affected the tolerance ability of FA of the granular sludge, in which the tolerance ability of FA would decrease in the operation of A and D. Strategies with high concentration of ammonium nitrogen will directly affect the removal ability of ammonium nitrogen ${ }^{5}$ during the reactivation period.

To investigate whether denitrifying or air stripping, the conversion rates of ammonium nitrogen $\left[\left(\mathrm{NO}_{2}{ }^{-} \mathrm{N}+\mathrm{NO}_{3}^{-}-\mathrm{N}\right) /\right.$ decrease in the amount of ammonium nitrogen] were analyzed (Fig. 3b). About $92 \%$ of the ammonium nitrogen had converted into nitrite nitrogen, and nitrate nitrogen under conditions of denitrification did not occur ${ }^{25}$. However, when comparing the four strategies of recovery, the generations of nitrogen oxide $\left(\mathrm{NO}_{2}^{-}-\mathrm{N}+\mathrm{NO}_{3}^{-}-\mathrm{N}\right)$ were $82.15 \%, 76.31 \%, 59.46 \%$, and $76.31 \%$ of the reduction of ammonium nitrogen, which were lower than the results of Bassin et al. ${ }^{25}$ This result was caused by the air stripping and occurrence of denitrification contributing to hierarchical structure of granular sludge. Meanwhile, compared with the previous conversion rate of ammonium nitrogen in the storage test, the conversion rate of ammonium nitrogen before storage was $84.16 \%$ higher than the value after storage. Therefore, the conversion rate of ammonium nitrogen before storage was closer to the theoretical value. The denitrification ability en- 


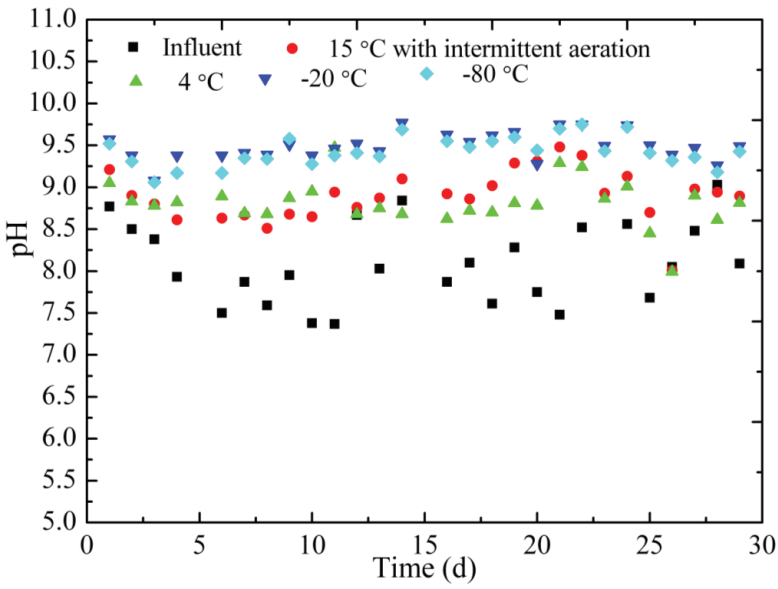

Fig. 4 - Variations in $p H$ during the reactivation period

hanced after a long period involving the anaerobic reaction inside the granular sludge. The denitrification ability of granular sludge was related to the particle size of granular sludge and the content of EPSs. The particle size of granular sludge was larger, which would increase the living space of denitrifying bacteria, because of the diffusion limitation of dissolved oxygen, but the high content of EPSs in the granular sludge would reduce the diffusion capacity of dissolved oxygen ${ }^{26}$. The particle size of the SNAGS was larger under the storage conditions of $15{ }^{\circ} \mathrm{C}$ and $4{ }^{\circ} \mathrm{C}$, and it should have higher denitrification abilities. However, the lower content of EPSs increased the diffusion ability of dissolved oxygen and reduced the denitrification ability of granular sludge. When comparing the storage conditions of $-20{ }^{\circ} \mathrm{C}$ and $-80{ }^{\circ} \mathrm{C}$, the SNAGS with a higher content of EPSs showed a more powerful denitrification reaction than the sludge with larger particle size ${ }^{27}$.

\section{Characteristics of nitrite accumulation}

The influence of the storage strategies on the process of nitrite accumulation was not great (Fig. 5). The nitrite accumulation rate was between $77.67 \%$ and $82.06 \%$, which was close to the previous value $(78.51 \%)$. Nitrite accumulation involved the amount and activity of the ammonia-oxidizing bacteria and nitrite-oxidizing bacteria, which influenced the result of nitrite accumulation in the system. Before storage, the ammonia-oxidizing bacteria existed as an advantage bacterium group characterized by a steady accumulation of nitrite. After storage, the number of ammonia-oxidizing bacteria and nitrite-oxidizing bacteria had different degrees of reduction, and the speed of reduction affected the change of dominant bacterial community. Yilmaz ${ }^{10}$ reported that the attenuation rate of ammonia-oxidizing bacteria was higher than that of nitrite-oxidizing bacteria. However, Salem et al. ${ }^{28}$ obtained a similar attenuation rate for ammonia-oxidizing bac-

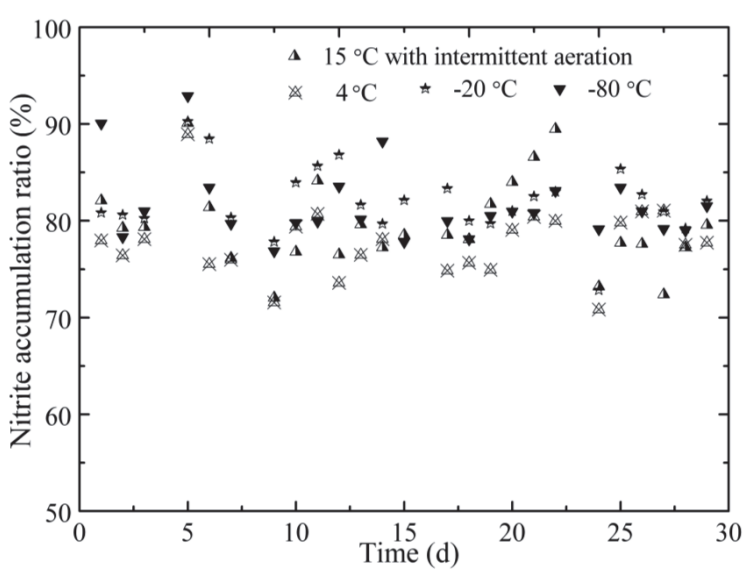

Fig. 5-Characteristics of nitrite accumulation during the reactivation period

teria and nitrite-oxidizing bacteria. The dominant bacterial community remained, even after experiencing a long period of hunger, and the effluent still gave priority to the nitrite. In addition, the higher concentration of the FA in the inflow (more than 4.5 $\mathrm{mg} \mathrm{L}^{-1}$ ) had obvious biological inhibiting effects on nitrite-oxidizing bacteria ${ }^{29}$. Results showed that the condition of nitrite accumulation remained unchanged after storage.

\section{Conclusion}

Storage strategies affected the particle size distribution of SNAGS, EPSs, tolerability of FA, and the oxidation of substrates. The granular sludge had a smaller particle size that decreased with storage temperature after 1 month of storage. EPSs, PN, PS of granular sludge and all decreased after storage. After storage, the tolerability of SNAGS to the FA decreased especially at $15{ }^{\circ} \mathrm{C}$ and $-80{ }^{\circ} \mathrm{C}$. Storage strategies affected the removal ability of the substrate in SNAGS.

\section{ACKNOWLEDGEMENTS}

This work was supported by Young academic backbone support project of Heilongjiang Province (NO. 1254G010).

\section{References}

1. Lee, D. J., Chen, Y. Y., Show, K. Y., Whiteley, C. G., Tay, J. $H$., Advances in aerobic granule formation and granule stability in the course of storage and reactor operation, Biotechnol. Adv. 28 (2010) 919. doi: https://doi.org/10.1016/j.biotechadv.2010.08.007

2. Tay, J. H., Liu, Q. S., Liu, Y., Characteristics of aerobic granules grown on glucose and acetate in sequential aerobic sludge blanket reactors, Environ. Technol. 23 (2002) 931. doi: https://doi.org/10.1080/09593332308618363 
3. J. R. Zhu, P. A., Wilderer, Effect of extended idle conditions on structure and activity of granular activated sludge, Water Res. 37 (2003) 2013. doi: https://doi.org/10.1016/S0043-1354(02)00585-7

4. Zeng, P., Zhuang, W. Q., Tay, S. T. L., Tay, J. H., The influence of storage on the morphology and physiology of phthalic acid-degrading aerobic granules, Chemosphere 69 (2007) 1751.

doi: https://doi.org/10.1016/j.chemosphere.2007.05.085

5. Wang, X., Zhang, H., Yang, F., Wang, Y., Gao, M., Longterm storage and subsequent reactivation of aerobic granules, Bioresour. Technol. 99 (13) (2008) 8304. doi: https://doi.org/10.1016/j.biortech.2008.03.024

6. Wan, C. L., Zhang, Q. L., Lee, D. J., Wang, Y. Y., Li, J. N., Long-term storage of aerobic granules in liquid media: Viable but non-culturable status, Bioresour. Technol. 166 (2014) 464.

doi: https://doi.org/10.1016/j.biortech.2014.05.091

7. Adav, S. S., Lee, D. J., Tay, J. H., Activity and structure of stored aerobic granules, Environ. Technol. 28 (2007) 1227. doi: https://doi.org/10.1080/09593332808618883

8. Gao, D. W., Yuan, X. J., Liang, H., Reactivation performance of aerobic granules under different storage strategies, Water Res. 46 (2012) 3315 doi: https://doi.org/10.1016/j.watres.2012.03.045

9. Lv, Y., Wan, C. L., Liu, X., Zhang, Y., Lee, D. J., Tay, J. H., Freezing of aerobic granules for storage and subsequent recovery, J. Taiwan Inst. Chem. E. 44 (2013) 770. doi: https://doi.org/10.1016/j.jtice.2013.01.012

10. Yilmaz, G., Lemaire, R., Keller, J., Yuan, Z. G., Effectiveness of an alternating aerobic, anoxic/anaerobic strategy for maintaining biomass activity of BNR sludge during longterm starvation, Water Res. 41 (2007) 2590. doi: https://doi.org/10.1016/j.watres.2007.02.011

11. Lee, Y., Oleszkiewicz, J. A., Effects of predation and ORP conditions on the performance of nitrifiers in activated sludge systems, Water Res. 37 (2003) 4202. doi: https://doi.org/10.1016/S0043-1354(03)00341-5

12. Yan, L. L., Liu, Y., Ren, Y., Zhang, Y., Analyses of the characteristics of short-cut nitrification-denitrification granular sludge and the removal processes of pollutants, Bioproc. Biosyst. Eng. 37 (2014) 125. doi: https://doi.org/10.1007/s00449-013-1006-3

13. APHA, 1998. Standard Methods for the Examination of Water and Wastewater, 20th ed. American Public Health Association, Washington DC.

14. Yan, L. L., Yu, L, Wen, Y., Ren, Y., Hao, G. X., Zhang, Y., Role and significance of extracellular polymeric substances from granular sludge for simultaneous removal of organic matter and ammonia nitrogen, Bioresour. Technol. 179(c) (2015) 460 doi: https://doi.org/10.1016/j.biortech.2014.12.042

15. Frølund, B., Palmgren, R., Keiding, K., Nielsen, P. H., Extraction of extracellular polymers from activated sludge using a cation exchange resin, Water Res. 30 (1996) 1749. doi: https://doi.org/10.1016/0043-1354(95)00323-1
16. Lowry, O. H., Rosebrough, N. J., Lewis, F. A., Randall, R $J$., Protein measurement with the folin phenol reagent. J. Biol. Chem. 193 (1951) 265.

17. Pijuan, M., Werner, U., Yuan, Z. G., Effect of long term anaerobic and intermittent anaerobic/aerobic starvation on aerobic granules, Water Res. 43 (2009) 3622. doi: https://doi.org/10.1016/j.watres.2009.05.007

18. Wang, Z., Liu, Y., Tay, J., Biodegradability of extracellular polymeric substances produced by aerobic granules, Appl. Microbiol. Biot. 74 (2007) 462. doi: https://doi.org/10.1007/s00253-006-0686-x

19. Wang, Y. Y., Zhou, S., Wang, H., Liu, Y., Qin, J., Lin, X. M., Comparison of endogenous metabolism during long-term anaerobic starvation of nitrite/nitrate cultivated denitrifying phosphorus removal sludges, Water Res. 68 (2015) 374 doi: https://doi.org/10.1016/j.watres.2014.09.044

20. Adav, S. S., Lee, D. J., Lai, J. Y., Proteolytic activity in stored aerobic granular sludge and structural integrity, Bioresour. Technol. 100 (2009) 68. doi: https://doi.org/10.1016/j.biortech.2008.05.045

21. Geets, J., Boon, N., Verstraete, W., Strategies of aerobic ammonia oxidizing bacteria for coping with nutrient and oxygen fluctuations, FEMS Microbiol. Ecol. 58 (2006) 1. doi: https://doi.org/10.1111/j.1574-6941.2006.00170.x

22. Yang, S. F., Tay, J. H., Liu, Y., Inhibition of free ammonia to the formation of aerobic granules, Biochem. Eng. J. 17 (2004) 41 doi: https://doi.org/10.1016/S1369-703X(03)00122-0

23. Yuan, X. J., Gao, D. W., Effect of dissolved oxygen on nitrogen removal and process control in aerobic granular sludge reactor, J. Hazard. Mater. 178 (2010) 1041. doi: https://doi.org/10.1016/j.jhazmat.2010.02.045

24. Liu, Y. Q., Lan, G. H., Zeng, P., Size-dependent calcium carbonate precipitation induced microbiologically in aerobic granules, Chem. Eng. J. 285 (2016) 341.

25. Bassin, J. P., Kleerebezem, R., Dezotti, M., van Loosdrecht, M. C. M., Measuring biomass specific ammonium, nitrite and phosphate uptake rates in aerobic granular sludge, Chemosphere 89 (2012) 1161. doi: https://doi.org/10.1016/j.chemosphere.2012.07.050

26. Chiu, Z., C., Chen, M. Y., Lee, D. J., Tay, S. T. L., Tay, J. H., Show, $K$. Y., Diffusivity of oxygen in aerobic granules, Biotechnol. Bioeng. 94 (2006) 505. doi: https://doi.org/10.1002/bit.20862

27. Maite, P., Werner, U., Yuan, Z. G., Effect of long term anaerobic and intermittent anaerobic/aerobic starvation on aerobic granules, Water Res. 43 (2009) 3622. doi: https://doi.org/10.1016/j.watres.2009.05.007

28. Salem, S., Moussa, M. S., van Loosdrecht, M. C. M., Determination of the decay rate of nitrifying bacteria, Biotechnol. Bioeng. 94 (2006) 252. doi: https://doi.org/10.1002/bit.20822

29. Anthonise, A. C. Loehr, N. R. C., Prakasam, T. B. S., Inhibition of nitrification by ammonia and nitrous acid, J. Water Pollut Control Federation 48 (1976) 835. 